\title{
Peace-Making, Adat and Tama Bulan Wang
}

\author{
Valerie Mashman \\ Associate Research Fellow \\ Institute of Borneo Studies
}

Corresponding author: Valerie Mashman (mashmanval@gmail.com)

\begin{abstract}
Resident Charles Hose was credited with "the true civilization of the Baram people." However, a careful examination of the role of Penghulu Tama Bulan Wang demonstrates that pacification of the Baram was achieved less by the mediation of Charles Hose and more by the role of local chiefs such as Penghulu Tama Bulan Wang. His source of power was the existing customary institution of chieftainship and the adat or system of customary law, which provided safeguards for preventing conflict, for making peace and creating alliances. The role of this local cultural component in establishment of the state of Sarawak has been underplayed in colonial accounts of peace-making and the contemporary written history of the state.
\end{abstract}

Key words: Adat, Baram, Hose, Kenyah, Peace-making, Tama Bulan

Copyright: This is an open access article distributed under the terms of the Creative Commons Attribution-NonCommercialShareAlike 4.0 International (CC BY-NC-SA 4.0) license which permits unrestricted use, distribution, and reproduction in any medium, for non-commercial purposes, provided the original work is properly cited.

\section{INTRODUCTION}

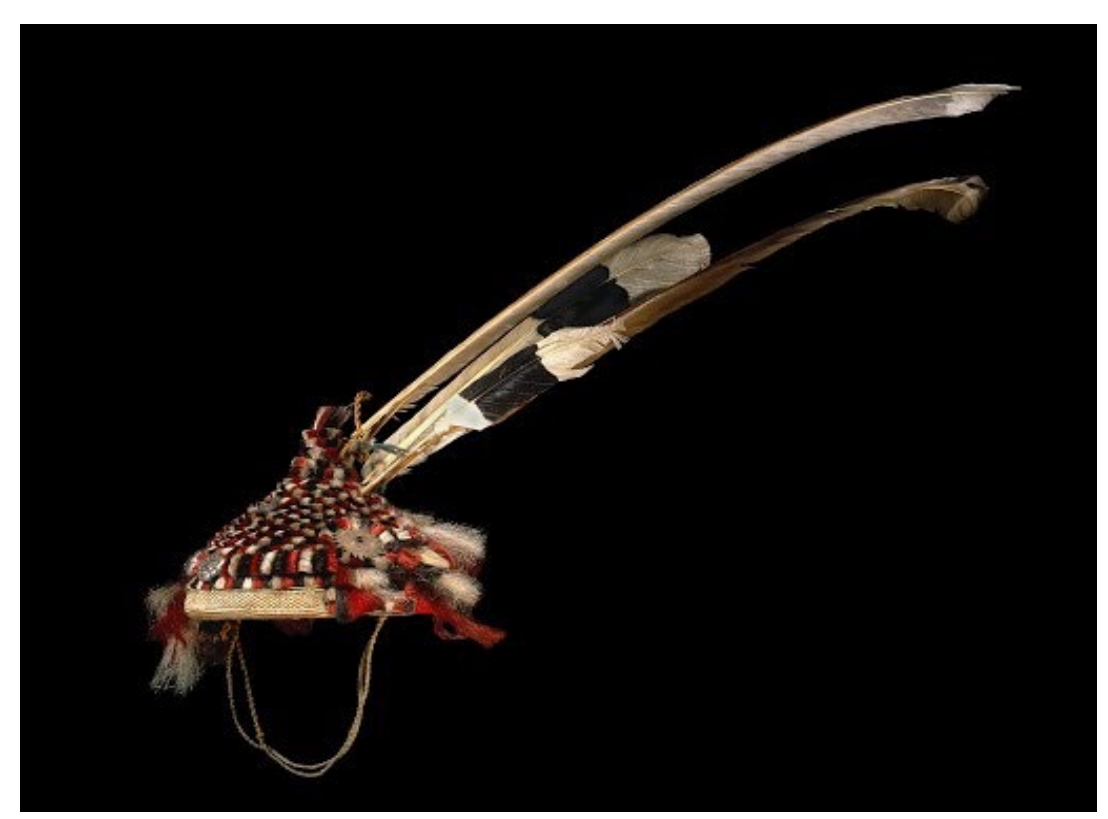

Plate 1: War-cap of Tama Bulan ${ }^{32}$

\footnotetext{
32 Image sourced from https://www.britishmuseum.org/collection/object/A_As1900-680 
Tama Bulan's war cap in the British Museum acquired by Resident Charles Hose, and his shield in the Museum of Archaeology and Anthropology in Cambridge, a personal gift to visiting anthropologist Alfred Cort Haddon, are very significant artefacts which are important to the narrative of the establishment of the state of Sarawak (Plates 1 and 2).

This is because without Tama Bulan, out of all the chiefs of the Baram district, the pacification of the Baram, of which the climax was the grand peace-making of 1899 in Marudi, would not have come about. This eventually led to the peace-makings in the Kelabit highlands in 1908, which included the Kelabit and the "border tribes," and in the Kapit peace-making in 1924 which brought together the local populations of Iban, Kayan, Kenyah, Kajang and their counterparts from the Apo-Kayan in Dutch Borneo. This is a departure from the conventional view that the transformation of the Baram is generally attributed to the Resident Charles Hose who according to Ranee Margaret, the wife of Rajah Charles Brooke, "achieved magnificent results...in the true civilization of the Baram people" (Brooke 1992:146).

In this article, I analyse the career of Tama Bulan and demonstrate how peace-making came about less by the influence and actions of Charles Hose and more through the agency of Tama Bulan, who worked through the existing customary institution of chieftainship, and the adat or system of customary law, which provided safeguards for preventing conflict from arising and for making peace and creating alliances. The pacification of the Baram was a key period in the establishment of the state of Sarawak, and this essential local contribution has hitherto been underplayed in written histories of the state.

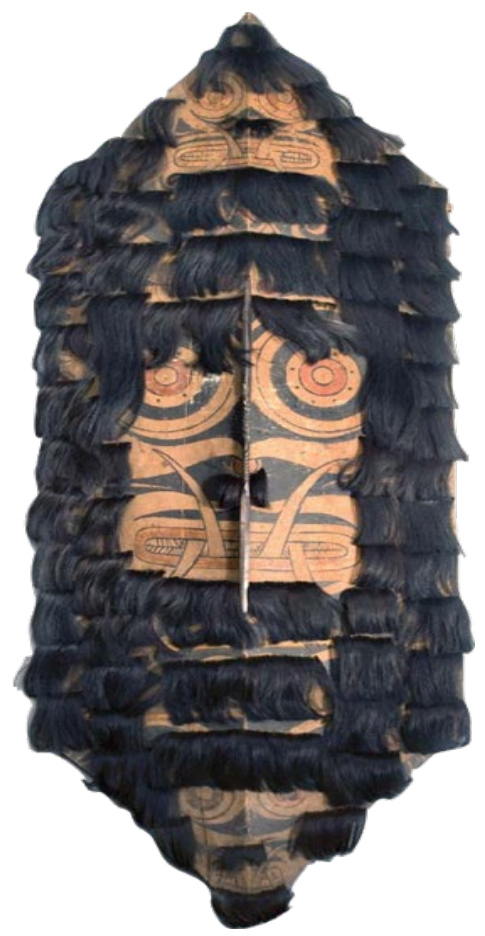

Plate 2: Shield of Tama Bulan ${ }^{33}$

\footnotetext{
${ }^{33}$ Image sourced from Elliot and Thomas (2011:42). 
In the first part of this article, I outline the function of the adat and the values upheld by Kenyah leaders, and I show how the agency of Tama Bulan was drawn from the value system and the Kenyah adat of peace-making petutung. The article will then cover in historical sequence the background of Tama Bulan, his role as a chief in the Baram, and how he dealt with the Brooke administration, warfare, peace-making and the great peace-making of 1899 in Marudi.

This paper is sourced by references to the photographs and books of Resident Charles Hose, the Brooke administrator for the Baram region, and his reports in the Sarawak Gazette (Hose 1988, Hose and Mc Dougall 1993a, 1993b). I also make use of the accounts and photographs of explorers and collectors hosted by Hose, such as the Americans James Austin Wilder and William Henry Furness (Appell 1968, Furness 1902). I also refer to the work of Haddon (1901), who was also hosted by Tama Bulan during his visit to the Baram 1898-1899. In order to get closer to local perspectives, I refer to an oral history collected by Tom Harrisson, deposited in the Echols Collection at Cornell (Harrisson 1948), narrated by Aban Uan Tingang, Tama Bulan's nephew. Further to this, in reassessing the role of Tama Bulan, I also have initiated a conversation with contemporary Kenyah local chiefs, Temenggong Joseph Ngau Lian and Tua Kampong Peter Edam during a recent fieldtrip ${ }^{34}$ to the upper Baram, who recall their own experience as community leaders as a means of reflection on this on-going narrative about peacemaking.

\section{ADAT, PEACE-MAKING AND CHIEFTAINSHIP}

This paper will demonstrate that adat is an essential source of political and ritual power, from which Tama Bulan derived his influence. Adat is still a relevant aspect of Kenyah culture today, and the following elucidation from a Kenyah perspective is useful:

Adat pertains not just to those aspects of religious life Westerners choose to call 'religion' or 'law', it underlies all aspects of Kenyah life including relations to other humans as well as the natural and supernatural world. When everything is acting according to its proper adat, there is harmony and balance. Wrong action, then, leads to an imbalance and sickness, death, crop failure and so on. The imbalance may occur in the world of men in which case redress may take the form of a fine or it may occur against the supernatural, in which case a ritual may be required as well (Whittier 1978a:117).

This definition makes for a much wider understanding of adat beyond its usual translation as custom, or customary law. The adat is the system of justice that regulated life in the longhouse and is at the basis of all relationships. The emphasis is always on consensus, because it is essential to contain disputes and create alliances to prevent the longhouse and the wider community from fragmenting, as division can cause the longhouse to split up. Decisions are made by the chiefs with the consent of the elders on behalf of the community. Adat is omnipresent and outsiders interacting with indigenous groups often underestimate its importance, as Whittier notes (1978b:104).

The chief is expected to uphold the values of the community. Chiefs are often praised in song for their virtues, reinforcing the values that they promote which build on their relationships within the community. The characteristics of a good leader are qualities that enhance relationships. For example, the Kenyah ideal leader is expected to be compassionate and socially responsible ('un lesau); ${ }^{35}$ polite in speaking and able to think rationally (tiga tira'ngan kenep); effective at uniting and advising people (mencam pebeka'ngan mencam pekatok dulu ngeleppo'); possess great determination and a sense of responsibility in leadership (bawa') and he should refrain from vilifying others (abe' uba 'pejaat dulu) (Topp and Eghenter 2006:46). These core values provide an impetus for leaders to take action to maintain and strengthen the community. Thus, the agency of leaders comes about when these values

\footnotetext{
${ }^{34}$ Lio Mato, February 2018. I wish to acknowledge my debt to the Sarawak Museum Campus for giving me the post of Assistant Research Fellow (2017-18) and assisting in the funding for this visit. Many thanks also to Jennifer R. Morris for her comments and encouragement. The comments of two reviewers have also been helpful.

35 These sayings are in the Kenyah Lepo' Tau dialect.
} 
are put into action. This is because action provides a bridge between values and what is desired (Mashman 2018:42).

It follows that the moral basis for a person's role in the community is logically founded on the adat and values of reconciliation which are based on humility and reflexivity. "To have sense of shame "un sae" is another core value of Kenyah leadership (Topp and Eghenter 2006:46). The importance of peace-making (petutung) in Kenyah ritual indicates that "a state of warfare was not really normal or desirable."

For a peace-making to take place the chiefs of the groups at war would agree, through a series of negotiations through trusted intermediaries, to meet to end hostilities. This meeting would be ideally held in a neutral village. The custom was that the side who had started the warfare, or who had taken the most heads, would offer pigs for sacrifice. The spirit of the pig would be asked to tell the spirits of the men slain in warfare to be appeased by the offerings, and that they should not cause trouble. If either party breaks its oath sworn in peace-making that "the spirits should take forthright action and punish the guilty." The spirit of the pig would be addressed and told that both sides wanted peace. Oaths taken over blood sacrifices were considered binding. There would be feasting held to show goodwill. Further to this a fine consisting of an agreed amount of prestige items such as jars, gongs or swords was given to the injured party, who would reciprocate with a return of gifts in the spirit of goodwill (Conley 1978:118-119).

Another rite related to peace-making was that of blood-brotherhood. The nature of the bloodbrotherhood rituals varied from place to place with the reciprocal smoking, licking, sucking and the swallowing of blood. Blood was extracted by making a cut on the hand or forearm of each of the parties involved. It was placed on tobacco which was then rolled into a cigarette, and on occasion invocations were made to "their god and all the spirits of good and evil to be witness of this tie of brotherhood" (St. John 1974:107). Then the parties involved would inhale the smoke of the tobacco that had been previously dipped in the blood of each party, accompanied by invocations to the spirits and the sprinkling of the blood of fowls and pigs on the parties involved. Such a pact was supernaturally binding, for which any betrayal incurred supernatural sanctions (Rousseau 1990:100).

For the Kenyah who wanted to travel to Marudi or visit relatives in the Apo Kayan, the making of blood-brothers meant becoming adopted as brothers into a community (sebila'). Once this ritual had been undertaken, the whole longhouse would provide shelter, protection and the means for safe journeys. After these rituals, which took place between individuals on their own terms people lived peacefully. Relationships forged between families of blood brothers continued for subsequent generations, as many Kenyah will testify today.

Penghulu Tama Bulan as a Kenyah leader held the key to bringing about peace-makings in the Baram, as will be discussed in the course of this article. His influence came through his maintenance of extensive alliances, which came about through kinship, marriage and blood-brotherhood. His allies would have shared this same world view and would uphold the sanctions of adat. This was the source of his power, influence and agency.

\section{BACKGROUND}

Tama Bulan was described by Furness, when he met him in 1896, as around forty-five and five and a half feet tall and well built. His bearing was "quite unobtrusive and dignified, and his voice soft and subdued" (Furness 1902:21). He was called Tama Bulan after his eldest child, Bulan, a young woman who had been on the verge of getting married three times but had been prevented by omen birds (Haddon 1901:376) (Plate 3). From this, it is possible to infer that she and her father upheld aspects of their conventional belief systems during a time of great change. 


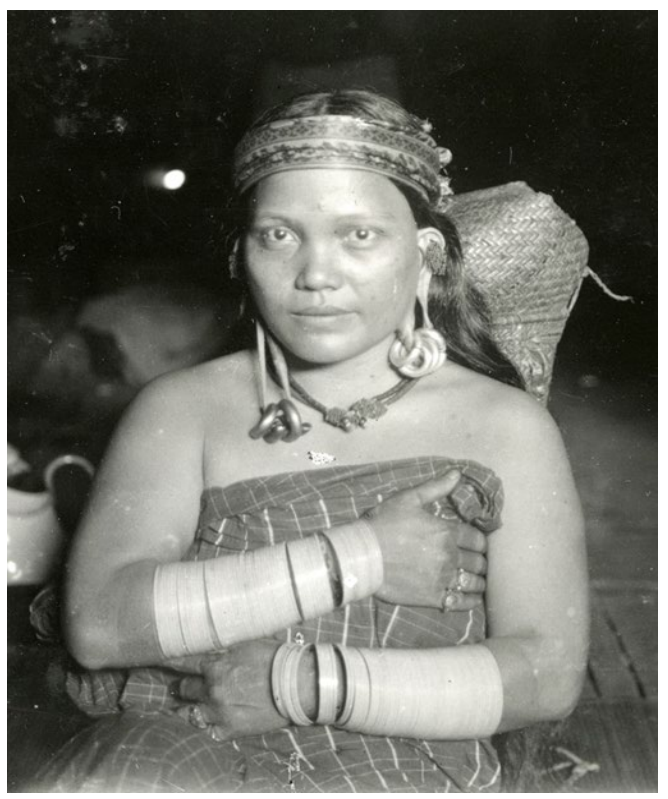

Plate 3: Bulan ${ }^{36}$

Tama Bulan's forbears, the Kenyah Long Tekan people, originated from the Usun Apau and migrated to the estuary of the Tekan stream and the Silat river, at a place called Long Tekan. His brother, Aban Tingang had a disagreement with their cousin Mueng Lawi and for a while the longhouse was split between locations at Long Pelutan and Long Arau on the Baram. Tama Bulan brought these two factions together and consolidated the family at a longhouse at Long Dalo on the Pata (Galvin 1975:81). The Long Tekan people were part of the Kenyah Lepo Pu'un which comprise of the earliest inhabitants of the Baram such as the Long Ulai, the Long Belukun, and the Long Sebatu, who outnumbered others in the Baram area (Daubeny 1888:80, Metcalf 2010:191). It is likely that Tama Bulan as a Kenyah chief, represented all these different peoples. Such hybrid identities reflect the places people migrated to and the intermarriages of communities during this era (Map 1).

${ }^{36}$ Reproduced by permission of University of Cambridge Museum of Archaeology \& Anthropology, P. 5064. 


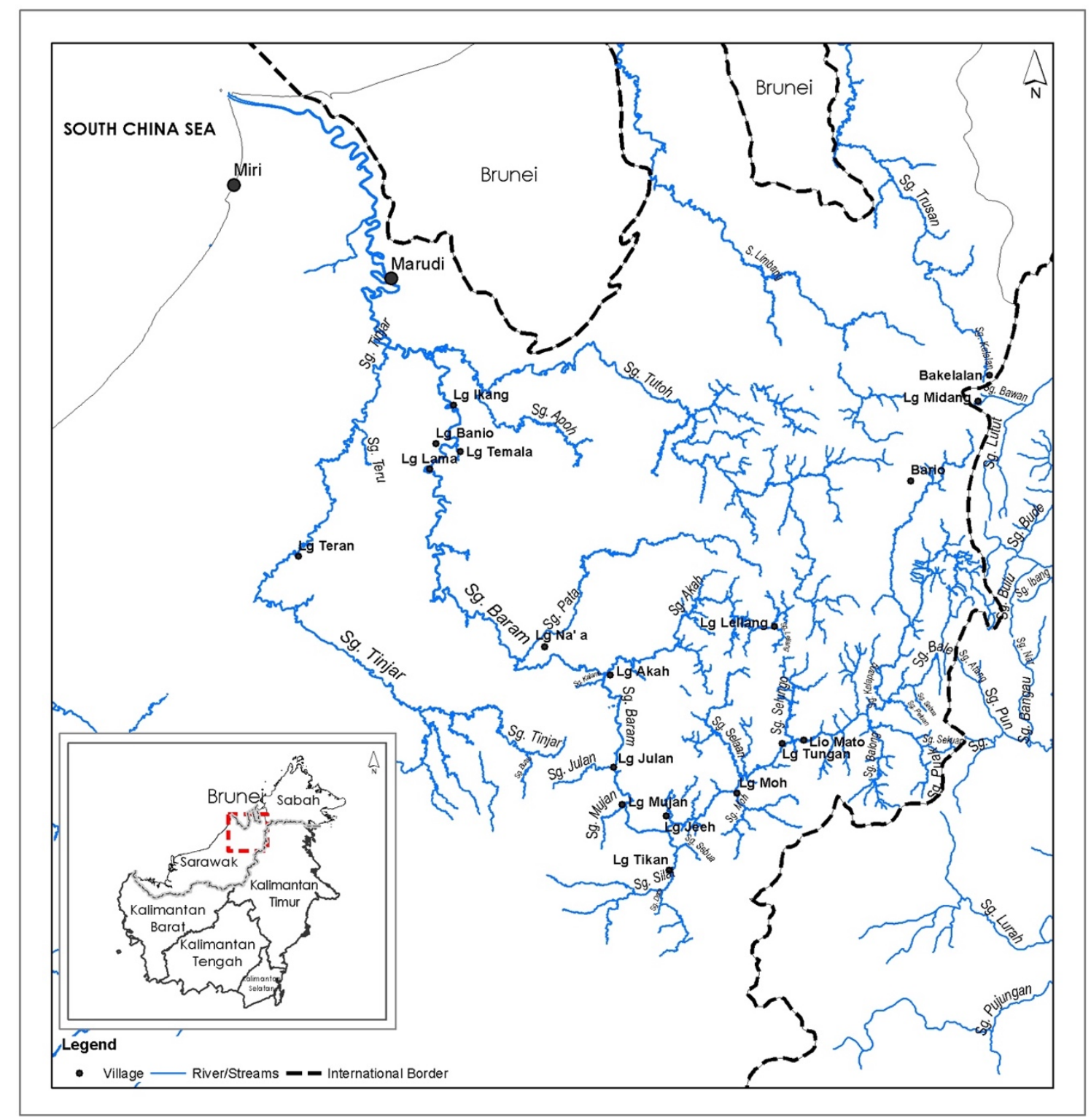

Map 1: Baram Area (Lee Guan Heng)

\section{EARLY CAREER- GIVING TAXES}

Tama Bulan first enters the pages of the Sarawak Gazette in the late 1880s and early 1890s as coming to Marudi to pay tax on behalf of the Kenyah (Hose 1891:56). Such visits gave him the opportunity to trade and to gain knowledge of what was happening in the wider world. Engaging with the new powerbrokers of the Brooke government in the Baram, who had replaced the influence of the Brunei Sultanate, gave him prestige in the eyes of his followers and the return to his longhouse with trade goods, heirloom objects (pusaka) and news of the outside world would consolidate his status. In the eyes of many upriver peoples, the payment of tax was less a symbol of submission but more an active contribution to a new source of power. Tax in the form of forest produce had previously been given to the Malay representatives of the Brunei Sultanate as a form of protection and allegiance. As an up-river informant recalls, "it was a matter of making the Resident part of our world, and this is what we did by giving him, rather than paying him tax". This local view of giving tax also occurs in a local narrative which describes this practice as a sequel to peace-making (Mashman 2018:206).

Giving tax to the Brooke administration brought an expectation of protection from attack from hostile people living outside the domain (Everett 1888:77). This was something of a development from 
the truculent era of Brunei rule, a time when warfare was rife. Paying tax was an institutionalized sequel to peace-making ceremonies as further demonstrated in photographs at Marudi during the great peacemaking of 1899 (Chua 2009:143). As Haddon observed:

"They prefer to pay the tax, because then they can feel they are citizens of the Raj, they really do belong to the Government... They know well that by paying two dollars a year they will have peace, be able to trade and have all the advantages of a settled Government, and they feel it is really a good investment for their money" (Hose 1900:59).

Tama Bulan emerged as an energetic mediator who visited the Resident to negotiate on behalf of his followers for deferral of payment of taxes because of problems such as famine caused by poor harvests (Daubeny 1886:195, Hose 1902:28). This demonstrates his sense of responsibility as a leader (bawa'). Most important for the Resident, he brought news on such visits of what was happening upriver, beyond the immediate realm of the Resident's office at the fort.

Thus, the administration became dependent on him to gain access to the chiefs and villages beyond the rapids upriver. He escorted the Resident to the upper Baram, where the Resident witnessed a demonstration of his influence over people and his ability to make a case for accepting the Brooke government and paying tax. He "was of the greatest assistance in explaining matters to the various chiefs and arranging for the payment of tax." Consequently, his chiefly status became officially consolidated as the Resident enthusiastically requested for an extension of his appointment to cover all the Kenyahs in the Baram (Daubeny 1888:79).

\section{WHO WAS TAMA BULAN?}

"Tama Bulan wore a Malay sarong and a gilt thread Malay cap. But no earrings. He wants to be considered civilized I think" (Appell 1968:428). This observation by William Henry Wilder, an American explorer and collector who visited the Baram as the guest of the Resident Charles Hose, provides a particular insight into the man (see sketch Plate 4).

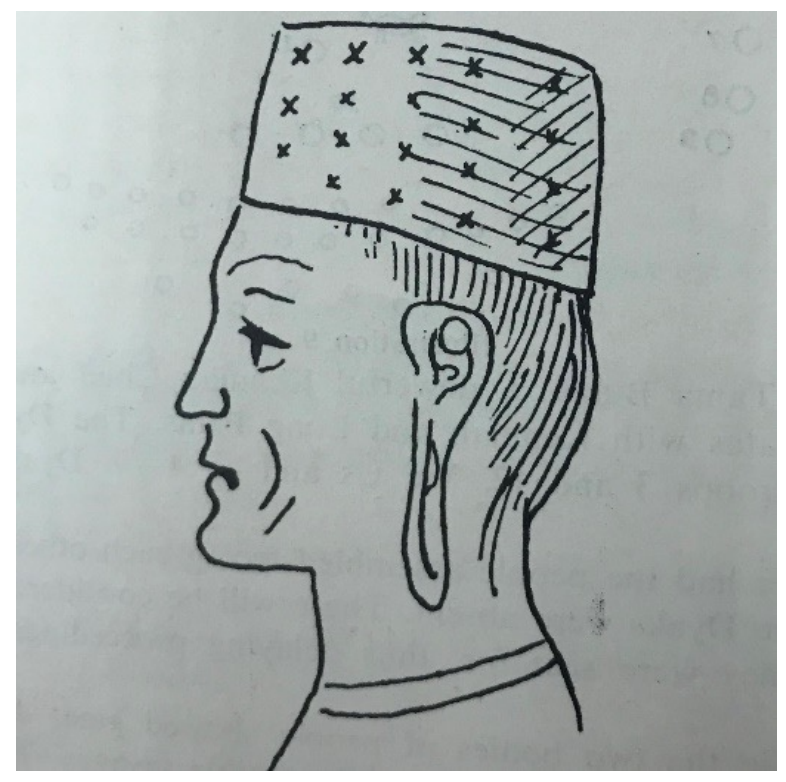

Plate 4: Tama Bulan by Wilder ${ }^{37}$

The context for this remark was a peace-making between the Kenyah, Kayan and the Dyaks (Iban) in May 1896 witnessed by Rajah Charles Brooke, Resident Charles Hose and William Wilder in Marudi. Tama Bulan was setting himself apart from his up-river contemporaries by dressing in this

\footnotetext{
${ }^{37}$ Image is sourced from Appell (1968:42).
} 
manner, thereby claiming a superior authority, aligning himself with the "civilized." The two parties of locals attending this meeting were dressed very differently, the Dayaks looked like "savages" dressed in war feathers and wearing yellow and red, and the upriver Kayan and Kenyah were dressed more plainly with woven skull caps. By abandoning earrings and the tribal dress of the loin cloth for a sarong on this occasion, he was not merely forsaking an aspect of his identity as a Kenyah chief, but clearly wanted to be accepted by the Malays who were the powerbrokers and traders in the Baram, on an equal basis. It is possible to infer that he wished to be on a par with the Malays, as an intermediary between the source of Brooke power and the Baram peoples. On another occasion, however, Tama Bulan was described as a more typical Kenyah by Wilder's contemporary Furness (1902:21), who emphasised his blackened teeth, his elongated earlobes, his upper ears pierced and plugged with wooden stoppers (Plate $5)$.

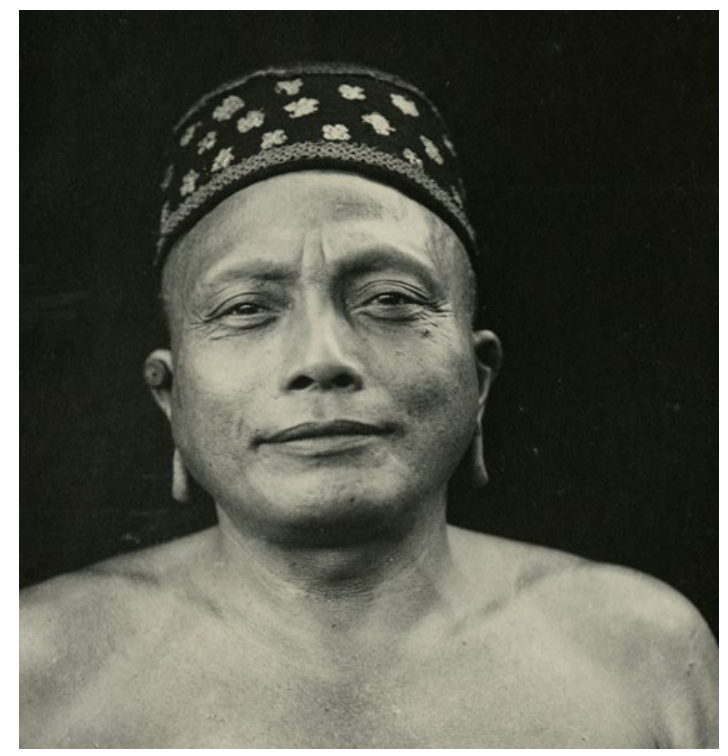

Plate 5: Tama Bulan ${ }^{38}$

These holes in the upper ear lobes, could sometimes serve as a place to put cigarettes and matches in lieu of pockets. Further to this, his hair was cut straight across the forehead with a longer cue at the back. His dress appeared to be that of an average Kenyah, wearing a bark cloth, cotton loin cloth and a rattan cap.

The description of the dress of the upper river chief who dresses like a "civilized" Malay contrasts with that of the Kenyah chief whose distinctive status is signified by his warrior's war cap, and shield, which are still today emblems of chieftainship. This contrast presents a visible manifestation of the differing roles of Tama Bulan, as he negotiated with the Resident at the centre of power in Marudi and with the up-river chiefs, while he led his people across an era of enormous change in the Baram.

\section{COSMOPOLITAN OUTLOOK}

Tama Bulan took advantage of his favoured position to request a passage to Kuching to the centre of the Sarawak government in 1891 (Hose 1891:127). This foreshadowed his role as one of the four native chiefs selected as Council Negri members (Furness 1902:20). His cosmopolitan outlook was not only governed by politics, but also economics. He embraced change readily and lobbied to have a government fort near his longhouse at Long Daloh on the Pata River which would be a centre for tax collection and trade (Hose and Mc Dougall 1993b:285). In fact, Hose had to give in to this request, even though he would have preferred this fort to be sited at Long Akah or Long Silat on the main Baram river (Hose 1998:169). There was no other chief in the Baram at this time who had a government fort

\footnotetext{
${ }^{38}$ Reproduced by permission of University of Cambridge Museum of Archaeology \& Anthropology, P. 52725.
} 
built next to his longhouse. Kenyah and Kelabit oral histories note that the Kelabit took an overland route and went to pay tax at this fort for some ten years (T.H. 48/4:17, Mashman 2018:165). The building of the fort at Long Daloh demonstrates an agency in Tama Bulan's attitude to governmentthat he did not see government as something imposed and distant but an institution to be embraced and brought into his own realm.

He taught himself to use an abacus with the help of a Chinese trader, a proficiency that would give him considerable advantage when clinching a trading deal. The skill of using an abacus went together with rise of the use of cash in transactions and the need to reckon on units of value in abstract terms, rather than in physical objects that are exchanged. The alternative would have been to assemble a few men and ask them to hold onto their fingers and toes to dealing with numbers exceeding twenty, a method commonly used at the time, which would be met with derision by other more sophisticated parties in the transaction (Hose and Mc Dougall 1893b:210-11).

He was open to meeting and providing hospitality for new visitors, such as William Henry Furness and Alfred Cort Haddon and was ready to grasp new theories and ideas. For example, Hose recalled that Tama Bulan discussed with him the idea of the earth revolving around the sun, a concept which he found difficult to grasp, as he declared he saw the sun move. However, Tama Bulan did not dismiss Hose's assertions immediately, but obtained confirmation for these new ideas by discussing them with other white men he had met. This led him to accept the idea when he found all white men said the same thing (Hose and Mc Dougall 1893b:215).

He was eulogized as being an "intellectual chief" after his death by Resident R.S. Douglas (Douglas 1905:68). This was a consequence of his open outlook, his readiness to adapt to change and learn new things, epitomizing the Kenyah value of having a broad perspective and an open mind ' $u$ n kenep iya dado' (Topp and Eghenter 2008:46).

\section{RELATIONSHIPS WITH VISITORS}

Tama Bulan, as a typical Kenyah leader, was an outward going, generous host and readily invited Hose's foreign guests to have the opportunity to experience his world, vicariously enhancing Hose's own prestige in the eyes of his visitors. In the accounts of Haddon, Furness and Hose, which at times are paternalistic and self-glorifying, Tama Bulan is referred to in terms of respect and admiration rather than deprecation. For example, Furness readily appreciated Tama Bulan's ability to take command of a dangerous situation, when emotions were running high, when his longhouse kin wanted to take the lives of Furness and Hillier to avenge the sudden death of a woman whom they had treated during a visit to Tama Bulan's longhouse (Furness 1902:52).

On other occasions, he was ready as the life and soul of the party, as at the time he caught up with Hose and Furness in the Tinjar to resolve difficulties with the Lirongs. He was aware that his presence was very important to Hose who admitted to relying on him for "the ceremonial peacemaking" (Hose 1994:122). He asked his hosts to use the traditional bamboo cups for their drinking session, possibly knowing that such items would be of interest to Furness, who was documenting the whole visit with photographs. He readily exhibited his skill in drinking and was met with a tremendous applause. The entertainment and feasting that went with drinking was an essential part of any peacemaking. This would join parties together in a spirit of goodwill and eradicate suspicion of poisoning from former enemies (Conley 1976:119).

Entertainment and feasting also created bonds between the Brooke Resident and chiefs such as Tama Bulan. This is demonstrated by his role in hosting a farewell for a visiting administrator, Pearse. He sang a traditional praise-song with improvised lines of eulogy, advice and good wishes to suit the occasion. He ironically deprecated his own style as "the manners of the children of the jungle," fully aware that his expatriate guests were happy with the "very pleasant evening for all concerned." 
Finally coming to the end of the song he bent forward and handed the glass to Mr. Pearse, and then with a mighty shout of wi! wi! wi! the whole assembly rose to their feet and commenced stamping and cheering and continued to make a most deafening noise until the last drop had been finished (Anonymous 1898:160).

It was the rapport created by such occasions that enhanced the standing of Tama Bulan as the host of the distinguished visitor. By taking on this role he is putting himself on the same level as his visitor, and by declaring "his manners and customs" are as "of the children of the jungle" he is in fact showing his "civilized" sensibilities. This provides some insight into the relationships between chiefs such as Tama Bulan and European Residents, such as Hose. It suggests that they viewed each other in such moments as equal partners, rather than a native leader subordinate to a European Resident, which was typical of the informality and mutual respect that was at times fostered by the Brooke administration.

\section{CONFLICT AND CHANGE}

Tama Bulan was living temporally between the two pre-Brooke and post-Brooke eras, of before and after head-hunting. This also put him in the middle of two parallel systems of law and order, that of the adat and that of the new court system of Pax Brookensis. While the Brooke administration outlawed head-taking and slavery, his own people had felt they had the right to take slaves in warfare, and to take the head of a female slave. Consequently, he had to pay compensation of 10 pikuls. Thus, he had the challenge of maintaining his position of loyalty to the administration and complying to the new dictates of the Brooke legislation, while at the same time maintaining his status in the eyes of his followers, who still adhered to the values of revenge, slavery and head-taking (Hose 1893:175).

Tama Bulan had to take responsibility for role of the Kenyah in the hostilities between them and the Iban collectors of wild rubber (known as gutta percha). The local Kenyah populations felt their territory was being encroached upon and were resentful of incidents of harassment and the exploitation of their lucrative forest resources by people they considered as outsiders. The Kenyah said their homes been threatened by spears poked through the floors of their longhouses giving rise to rumours of headhunting (penyamun). A series of thirteen head-takings took place by Kenyah in the Pata, Pelutan and Apoh rivers enraged the Dayaks in the area. With shrewd diplomacy, Tama Bulan took responsibility and surrendered the heads immediately and pragmatically informed Hose that he would accept any punishment, and he paid three thousand dollars compensation (Hose and Mc Dougall 1993b:300). At the same time, he held his ground, in stating his position asserting that Hose should keep the Dayaks away from his people. These negotiations resulted in the peace-making described earlier in 1896 by Wilder in which Tama Bulan presided in Malay dress, which set him above his antagonists. His handling of this situation earned Hose's respect, "as a Penghulu he has been of the greatest value in this river...he is a man of good common sense" (Hose 1894:207). Hose was always fulsome of his praise of Tama Bulan, yet he failed to convey an understanding of the very nature of his influence and power, which were so essential to Hose's mission of the pacification of the Baram.

It is possible to make a case that without Tama Bulan, Hose would have been unable to cope with escalating violence within the Baram basin. Hose was quick to recognize his competence in his effective handling of another difficult undertaking. He was entrusted to deal with the murderers, who were Lirongs, of Ah Pin, a Chinese trader on the Tinjar river. This was an area outside of Tama Bulan's geographical jurisdiction, but he was entrusted with the task to kill or capture the murderers, but to spare the lives and property of their relatives. When the murderers did not surrender, they were killed by his men, who also were about to kill their companions. Tama Bulan intervened throwing his own men in the river, preventing further loss of life and eventual reprisals. This earned a commendation by Hose for "the skilful and moderate way in which he carried out his duties" (Anonymous 1897:136). It was reported by Hose that Tama Bulan's conduct on such a mission was fuelled by his desire to demonstrate his loyalty to the Brooke government, which was on a par with any of the Dyaks who were paid to defend the fort and to go on expeditions at the behest of the government: 
Tama Bulan has managed the whole affair with great tact and before he started, I was convinced that he intended to keep his force well in hand, as his last words to me before leaving were "The Rajah and everyone else shall know that we Kenniahs can be trusted to carry out his instruction- and that we are as loyal to the Sarawak Government as any of his Dyaks" (Hose 1897:147).

Tama Bulan became politically aligned with Hose and had to accept the consequences of becoming subject to the Lirongs' desire for revenge for the action taken against their kinsmen who had murdered the Chinese Trader in the Tinjar. Thus, the images of Hose and Tama Bulan were made into "blood thirsty effigies" (Plate 6) (Hose 1994:128). ${ }^{39}$

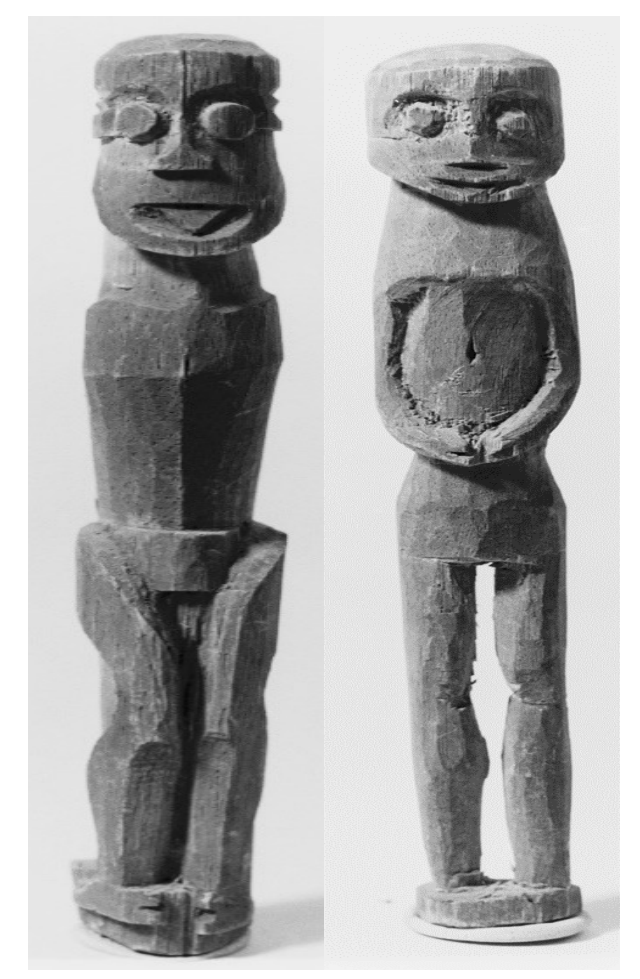

Plate 6: Effigies of Tama Bulan and Hose $e^{40}$

These were placed in the forest by the Lirong to decay with the intention of bringing about the deaths of their enemies (Furness 1902:93). Tama Bulan was disturbed by this and insisted a public revocation of the curse (Hose and Mc Dougall 1993b:119). Despite this, and the subsequent peacemaking with the Tinjar chiefs witnessed by Furness in October 1997, the antagonism between the Lirong and Tama Bulan was to become a strong undercurrent at the Marudi peace-making, which is discussed in a later section of this paper.

\section{PEACE-MAKING WITH THE BADENG ${ }^{41}$}

Tama Bulan was instructed to encourage the Badeng who were fleeing from the Usun Apau to settle in Sarawak in 1895 and 1896. They went to Marudi in October 1896 and Hose describes the peace-making meeting as "jovial" and "spirited" (Hose 1896:249). The next peace-making that was reported took

\footnotetext{
${ }^{39}$ Durrans is mistaken in asserting that Hose did not mention these effigies. He mentions them to highlight his own bravado in engaging with the Lirong at the Tinjar peace-making (Durrans 1993:xxx, Hose 1994:128).

${ }^{40}$ Images sourced from Durrans (1993:xxxi).

${ }^{41}$ Badeng is the preferred term and spelling used by the Badeng themselves. For example, their association is called Persatuan Kenyah Badeng. Badang is an alternative spelling sometimes in use. The Brooke administration referred to the Badeng as Madang.
} 
place over March and April 1897 in Marudi, after some further 2000 Badeng had moved into the Silat. After a meeting in Marudi, the Badeng chiefs Usun Tassi, (also known as Tasek Balang, Tasi Balan) Saba Irang and Saba Lahing the chief of the Uma Longs, went to Tama Bulan's house at the Pata River where they made peace with the Baram people. The prestige Tama Bulan gained was enhanced by his ability to provide hospitality and food for a thousand guests over five days.

Some of the Lepo Tau who had no provisions were taken in by Tama Bulan, and two bags of padi seed were given to the rest. Hose readily acknowledges the centrality of Tama Bulan's role in bringing about this peace-making:

Tama Bulan deserves special mention for the way in which everything has been carried out, and it is evident that the completeness with which things have been settled has given general satisfaction throughout the whole district (Hose 1897:113).

An oral history gives the account of the way in which Tama Bulan organized support for the Badeng and this peace-making. He organized all the longhouses on the Pata, Akah and Baram rivers to contribute supplies for the displaced Badeng and their relatives (Harrisson 1948). See Box 1 below:

\section{Box 1: Tama Bulan collects supplies for the destitute Badeng}

After that Tama Bulan asked some people to go down river to bring knots of appointment to the people downriver and asked them to bring rice, parang, axes, white cloth and salt. The longhouses down river were Long Ikang, Morek; Rumah Ake, Kayan; Long Lama; Long Manyin; Rumah Bawang and Long Luting.

The longhouses in the Pata were Lepo Ga, Lepo Lutong, Lepo Abong, Likan, Lepo Jangan and Long Bikan.

Those in the Akah river were Long Semai, Long Tabangan, Long Tap, Lepo La'ang Ta'uan, Long Belukun Apo, Ruma Pawa, and Long Julan.

On the appointed day all those people who had been summoned came. They brought many things with them, such as salt, rice, parangs and axes. The same with cloth balachu. The smaller longhouses brought four or five rolls, the big longhouse seven to eight.

\section{Conference at Long Tikan}

Then the people went upriver and entered the Silat river as far as Long Tikan. That was the meeting place. Then they built a "laga" and huts after which, the conference started.

Tama Bulan spoke: Tama Suleng Anyi, Ukat Anyi, Tama Bilong Apoi, Awal Used Tuan, Tama Ja Lian, I had received a letter from Tuan Aut which said you had been attacked at the upper Plieran. I was worried because of our relationship. I do not want you to escape to unsuitable places though we can't help those who have already gone to the Batang Kayan.

...After that they collected the cloth and other things in great quantity. Long Tikan alone contributed 15 boxes, 10 parangs, 180 gantangs salt, a big quantity of rice and 34 rolls of belachu. All the cloth collected amounted to 80 rolls.

There were also some Iban people who had been working collecting wild produce in the jungle. They were also called by Tama Bulan to aid the distressed people and they brought with them four big baskets of wild sago. Their leaders were Bandong and Salpo and they were more than thirty in number.

Then the food and clothing were given out. After that parangs and axes were shared among them. Source: Harrisson (1948). 
This narrative is sourced from Tama Bulan's own nephew, Aban Uan Tinggang. It was possibly circulated to keep an account of what was given so that the incoming Badeng would be indebted politically and economically to all these longhouses and to Tama Bulan. It demonstrates Tama Bulan's influence and ability in organizing aid for the displaced Badeng, who had become homeless after the Brooke sponsored expeditions against the Usun Apau in 1895 and 1896 (Mashman 2019:425). It also shows also that he had influence as a leader not just over the Kenyah, but also the Kayan and Iban as well.

A year later, Tama Bulan accompanied Hose on the epic journey up the Silat River to meet the Badeng in the headwaters of the Lata River in October 1898 to visit the villages of the leaders Saba Irang and Tama Usun Tasi (Hose 1899a, 1899b, 1900). On this occasion Hose, as Resident, provided protection as Tama Bulan was going into territory where there were still enmities and unsettled blood debts. The Kayan accompanying Tama Bulan turned back, because they were afraid of uncertain omens and of going into unknown territory. For Hose, it was a formidable journey with Tama Bulan's men having to haul him over rocks and rapids in a boat that was barely big enough for his ample body.

Tama Bulan and his followers, being unable to enter the Badeng village until all cases of bloodmoney between his people and the Madangs had been negotiated, were obliged to camp near the river for one night.

Eventually, the problems between Tama Bulan and the Badeng were favourably resolved. Hose was greatly encouraged by the outcome of the event and the compliance of the Badeng in paying taxes and delegated Saba Irang and Tasek Balang (also known as Tasi Balan, Usun Tassi) as ambassadors to encourage the Batang Kayan chiefs to come for peace-making. Saba Irang appeared to be very happy to be entrusted with this mission and handed Hose a large shield to be given to the Rajah as a symbol of his "good intentions" to live in peace. For Hose, the final submission of paying taxes by the Badeng meant that all the tribes of the Baram had accepted the power of the Brooke administration and that this would open greater opportunities for trade, particularly with the Batang Kayan chiefs (Hose 1899a, 1900).

For Tama Bulan, this peace-making was a significant political and economic coup. He had averted the prolonging of a feud between his people and the Badeng and the Lepo Aga who were a sizable force to be reckoned with, given their allies in the Batang Kayan. He had done this by the payment of blood-debts and the provision of goods which would have earned him considerable goodwill.

\section{GREAT SAVAGE PEACE-MAKING IN MARUDI 1899}

These events prepared the way for the peace-making in Marudi in April 1899 in which 6000 people attended. Hose subsequently called it a Great Savage Peace-Making ${ }^{42}$ to elevate his achievements to a western audience. He used the occasion to build his reputation on the prestige of the event in the eyes of his guests from Cambridge who included Dr. Haddon, Dr. Mc Dougall and other members of the Cambridge Torres Straits expedition. The main objective of this event was to "encourage the Madang (Badeng) to be loyal subjects and to ensure a friendly recognition by them by the Baram people" (Haddon 1899:85).

The main parties that took part at the ritual peace-making were Saba Irang for the Badeng, Taman Oding Silong and Taman Balang Den, for the Kenyahs and Long Pokun, Tama Aping Bulieng and Jangan for the Tinjar peoples and Tama Bulan for the Baram peoples (Haddon 1899). One European observer, William Mc Dougall, described this as "an interesting and speculative experiment in peace-

\footnotetext{
${ }^{42}$ See Hose (1988:155). Curiously, he states that it took place in 1898 which contradicts reports in The Sarawak Gazette by Hose (1899b) and Haddon (1899).
} 
making," as so many armed groups of warriors were coming together in one place (Hose and Mc Dougall 1993b:294).

However, behind the scenes the groundwork must have been made by Tama Bulan and the other chiefs over a long period to achieve a grand large-scale public event. They were working according to the tenets of their adat so for them, things were less tentative and experimental that the Badeng could witness the support that Hose had garnered from the other Baram tribes. This is borne out by a comment made by Temenggong Joseph Ngau Lian the paramount chief of the Kenyah when reflecting on the photograph of this meeting (Plate 7).

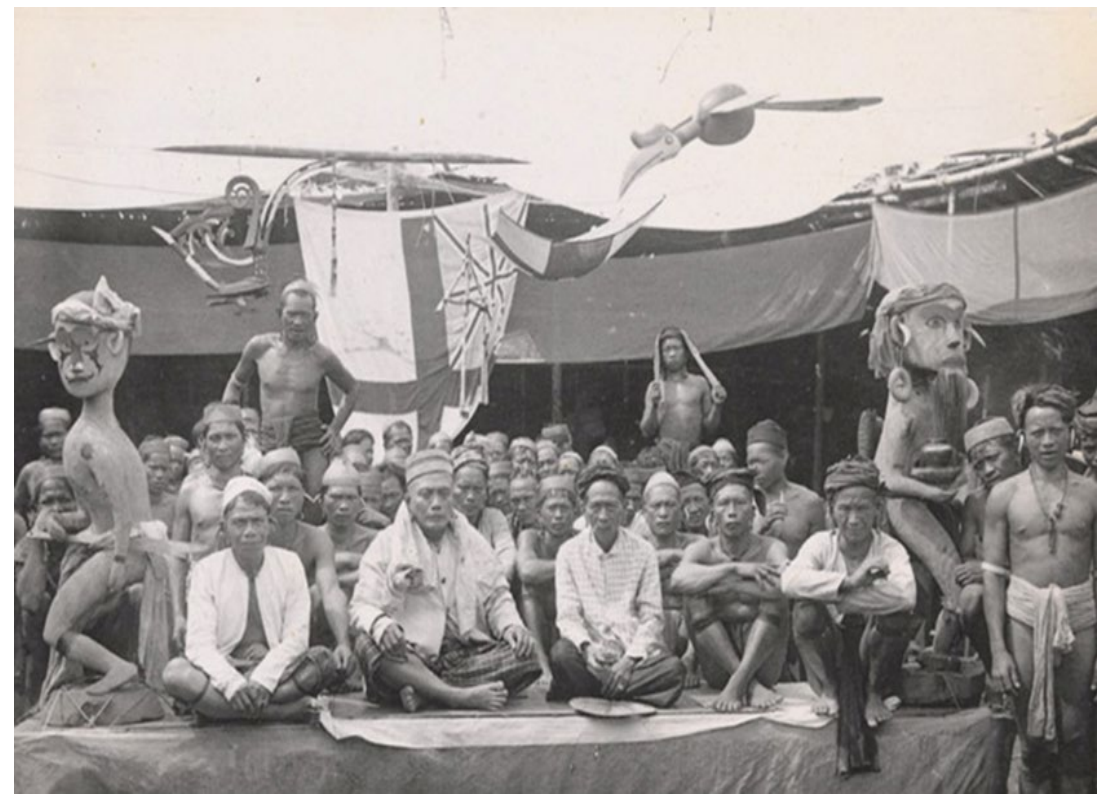

Plate 7: Marudi Peace-making $1899^{43}$

From his experience as the paramount chief of the Baram Kenyah, he considered how the event must have entailed lengthy preparation based on the adat. This would have involved checking the phase of the moon in advance, observing bird and animal omens and making lengthy negotiations with all the local chiefs, suggesting from the local perspective the rituals and symbols of the event were following the customary law and there was a solid purpose and rationale for everything that was being undertaken. This highlights how this must have been quintessentially a local event based on local custom and values, and that the Kenyah chiefs had played a significant part in determining symbolic material aspects of the rituals. The huge penchallong or hornbill which was constructed with a head carved by the Iban fortmen and with Badeng shields making the body, imitated a Kenyah and Badeng custom of making hornbill effigies, shaped like a bird about to fly, out of whatever materials were available, for festivals and meetings (Vom Roy 1993:50, 60) (Plate 8).

\footnotetext{
${ }^{43}$ Reproduced by permission of University of Cambridge Museum of Archaeology \& Anthropology, P. 52707.ACH2
} 


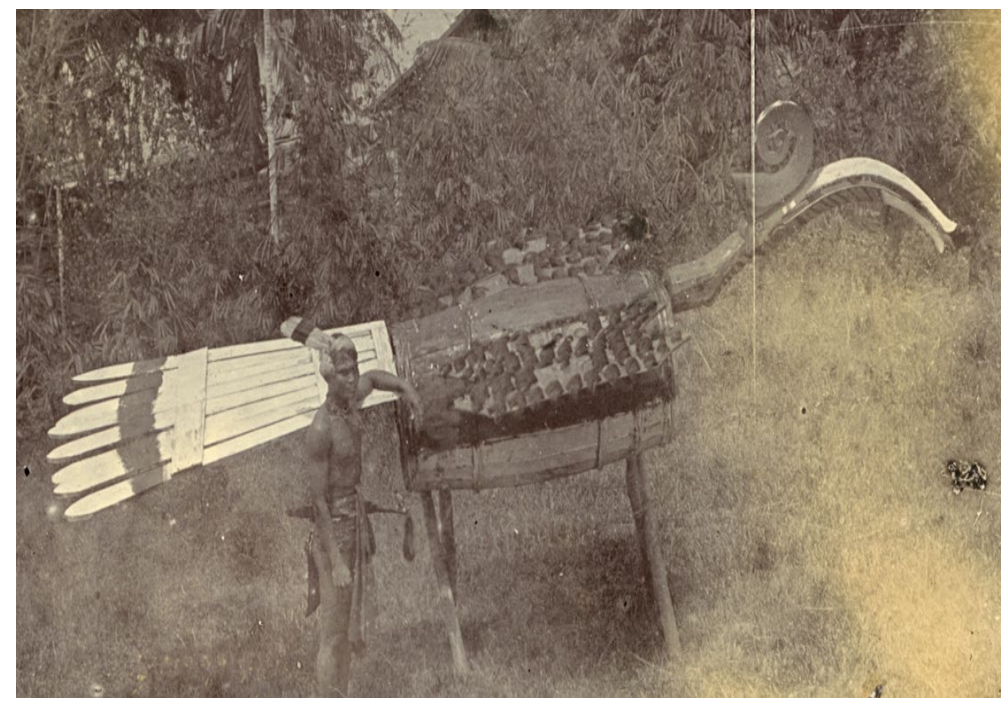

Plate 8: Penchallong or Hornbill ${ }^{44}$

Tama Bulan became a casualty with an eye injury during the peace-making as a consequence of unresolved tensions with the Lirongs. Despite the success of the first performance of ritual warfare, the Tinjar people attempted to attack the Baram chiefs and Tama Bulan was injured above the eye with blood pouring on his face. It was observed that Tama Bulan "showed his true greatness" by playing down his wound saying it was accidental and his allied counterpart chiefs held back their men, preventing them from retaliating. Although it was noted that the white men stood between the two opposing parties to form a barrier to confrontation it can be argued that it was the conduct of the chiefs that defrayed tensions that could have caused an outbreak renewed hostilities (Hose and Mc Dougall 1993b:296).

This leads to a consideration of the significance of local institutions in the effectiveness of peacemaking. It is difficult to conceive that the major peace-makings that took place on the Baram in the 1890s would have happened without there being provision in the adat for peace-making. This is particularly relevant to the case of the adat of the Kenyah, which had a provision for petutung or peacemaking, as discussed earlier.

\section{THE LOCAL BARAM CHIEFS, ADAT AND PEACE-MAKING}

As discussed above, peace-making was something that was inherent in the adat of the Kenyah and the word petutung is used to describe the process. This contrasts with the Iban who did not have a customary law, nor a term related to peace-making in pre-Brooke times (Pringle 2010:239). Contemporary Kenyah explain petutung as follows in the words of TK Peter Edam: "Petutung means to make speeches, to take oaths, to eat together. You literally burn grudges. You tie the pig and you spear it. You look at the liver you exchange objects gongs and parangs." The etymology of the word originates from the word to burn petutung "In the same we burn the land to clear it and make it fertile to produce a fruitful yield on our padi farms, we burn away our old grudges, through peace-making to have a better life." Temenggong Joseph Ngau Lian confirms this idea that the concept of a better life was very much a goal of peace-making. To him the values of peace-making are considered in these terms: "petiga udip a very good life, peteneng udip an upright life."

Peace-making was based on local custom, oaths were taken pigs were slaughtered their entrails were examined for omen. Former enemies became sworn as blood brothers, through rituals which involved the reciprocal ingestion of blood. Exchanges of gifts such as weapons, beads or brassware were carefully negotiated and the peace-making meetings were rounded off with feasting and the

\footnotetext{
${ }^{44}$ Reproduced by permission of University of Cambridge Museum of Archaeology \& Anthropology, P. 50203.ACH2
} 
imbibing of rice wine. Temenggong Joseph when asked about how debts were measured and assessed when preparing for the exchange of gifts indicated that that there had to be careful arbitration before the exchange to prevent misunderstandings.

The establishment of the Resident in the Baram and the abolition of head-hunting brought about a new era on the Baram whereby the local chiefs were ready to create more alliances which would facilitate smooth journeys and easy trade networks. It was in their interest to promote peace and trade, as they could see the opportunities provided to acquire prestige goods that would boost their status. So, in actual fact, peace-making was less the achievement of Hose, as a Brooke administrator, but came about through the consistent mediation of local chiefs whose conduct influenced their followers. Hose himself identifies the effects of their influence: Tama Bulan..."spared no efforts to bring about friendly meetings between chiefs of different tribes, for the purpose of making peace and of promoting intercourse and mutual understanding" (Hose and Mc Dougall 1993b:206). At the same time Hose recognized qualities in Tama Bulan which he must have considered on a par with any other "civilized" person. He declares that he "displayed high degree of enlightenment and moral qualities of a very high order" (Hose and Mc Dougall 1993b:281). Underlying such generous praise was an ignorance of the power of the adat as a local institution. If Hose had appreciated and understood this, his contemporary and guest anthropologist A.C. Haddon may have modified his statement that the peace-making was initiated and guided by the "moral force of the white man" (Haddon 1899:87)

\section{CONCLUSION}

In this paper I have highlighted the role of Tama Bulan in bringing about the pacification of the Baram. As a Penghulu, he demonstrated the attributes of a respected chief, exercising restraint and control, and was able to influence other tribes into paying tax and accepting Brooke rule, particularly the Badeng. His generous hospitality and open attitude to Europeans made him an essential intermediary and guide for the collectors for Furness's and Haddon's scientific and ethnological expeditions. He presented himself as a "civilized chief" which earned him the status of an equal to Hose and his visitors. This was something of a departure for relations between Europeans and their subject peoples in the colonial era. The origin of his power was in the adat, which made provision for peace-making and the formation of new alliances, and this guided his values as a chief. Adat had its own mechanisms for social control which embraced both the natural and supernatural worlds, and European observers and administrators, such as Hose and Ranee Margaret, fell short of understanding that this was a fitting counterpart to Western notions of "civilization."

His war cap and shield are artefacts that speak of his distinction among his own people, not only as an able and honored warrior, but as an able defender and an upholder of the values of the adat. 


\section{REFERENCES}

Anonymous, 1897. The Tinjar Murderers. The Sarawak Gazette 379: 136.

Anonymous, 1898. The Hon C.S. Pearse's Visit to Baram. The Sarawak Gazette 391:160.

Appell, G. N 1968. The Journal of James Austin Wilder During his Visit to Sarawak in 1896- Part 1. The Sarawak Museum Journal XV1, 32-33: 407-434.

Brooke, M. 1992. My Life in Sarawak. Singapore: Oxford University Press.

Chua, L. 2009. A Cambridge Anthropologist in Borneo: the A.C. Haddon Photographic Collection,1898-1899. Borneo Research Bulletin 40:129-146.

Conley, W. W. 1976. The Kalimantan Kenyah: A Study of Tribal Conversion in Terms of Dynamic Cultural Themes. United States: Presbyterian and Reformed Publishing Company.

Daubeny, C.W. 1886. The Sarawak Gazette 251:195 -196.

Daubeny, C.W. 1888. The Sarawak Gazette 289:80.

Douglas, R.S. 1905. Baram: Monthly Report February. The Sarawak Gazette 470:68.

Durrans, B. 1993. Introduction. Pagan Tribes of Borneo Volume 1 by Charles Hose and William Mc Dougall, pp.vii-xli. Singapore: Oxford University Press.

Elliot, M. and Thomas, N. 2011. Gifts and Discoveries: The Museum of Archaeology and Anthropology Cambridge. London: Scala publishers.

Everett, A.H. 1888. Monthly Report Baram District. The Sarawak Gazette 269:77-78.

Furness, W.H. 1902. The Home Life of the Borneo Head-hunters: its Festivals and Folk-lore. Philadelphia: J.B. Lippincott Company.

Galvin, A.D. 1975. The Passing of a Kenyah Chief. The Sarawak Museum Journal XX111, 44:81-90.

Haddon, A.C.1899. Peace-making at Baram. The Sarawak Gazette 400: 85-87.

Haddon, A.C. 1901. Headhunters, Black, White, and Brown. London: Methuen.

Harrisson, T. 1948 Tuan Aut and Tama Bulan. Manuscript 48/4 Echols Collection. Cornell University.

Hose, C. 1889. Baram Monthly Report. The Sarawak Gazette 284:134.

Hose, C. 1891. Baram Monthly Report. The Sarawak Gazette 303:56.

Hose, C. 1891. Baram Monthly Report. The Sarawak Gazette 307:127.

Hose, C. 1893. Baram Monthly Report. The Sarawak Gazette 334:175

Hose, C. 1894. Baram Monthly Report. The Sarawak Gazette 347:207.

Hose, C. 1896. Baram Monthly Report. The Sarawak Gazette 371:248-249. 
Hose, C. 1897. Baram Monthly Report. The Sarawak Gazette 377:113.

Hose, C. 1898. Baram Monthly Report. The Sarawak Gazette 391:169-170.

Hose, C. 1899a. Baram Monthly Report. The Sarawak Gazette 396:16-17.

Hose, C. 1899b. Baram Monthly Report. The Sarawak Gazette 402:241.

Hose, C. 1900. Into the Heart of Borneo. The Geographical Journal Vol.16, No.1:39-59.

Hose, C. 1902. Baram Monthly Report. The Sarawak Gazette 379:147.

Hose, C. 1988. Natural Man A Record from Borneo. Singapore: Oxford University Press.

Hose, C. 1994. Fifty Years of Romance and Research. Singapore: Oxford University Press.

Hose C. and W. Mc Dougall. 1993a. The Pagan Tribes of Borneo. Volume 1. Singapore: Oxford University Press.

Hose, C. and W. Mc Dougall. 1993b. The Pagan Tribes of Borneo. Volume 2. Singapore: Oxford University Press.

Mashman, V.A. 2018. A History of Lun Tauh Our People at the Borders of the Kelabit Highlands: from Warfare, to the Life of Government and to the life of Christianity. PhD Thesis. Universiti Malaysia Sarawak.

Mashman, V.A. 2019. 'Looted in an expedition against the Madangs': Decolonizing History for the Museum. Volkskunde: Tijdschrift over de cultuur van het dagelijks leven 120 (3): 407-432.

Pringle, R. 2010. Rajahs and Rebels Kota Samarahan: UNIMAS.

Rousseau. J. 1990. Central Borneo: Ethnic Identity and Social Life in a Stratified Society. Oxford: Clarendon Press.

St. John, S. 1974. Life in the Forests of the Far East. Volume 1. Singapore: Oxford University Press.

Topp, L. and C. Eghenter. (eds.). 2005. Kayan Mentarang National Park in the Heart of Borneo. W.W.F. Denmark in collaboration with W.W.F. Indonesia.

Vom Roy, 1993. The Migration of the Kenyah Badang: A Study based on Oral History. Institute of Advanced Studies Universiti Malaya.

Whittier, H.L. 1978a. The Kenyah in V.King (ed.) Essays on Borneo Societies. Hull Monographs on Southeast Asia No.7. Oxford: Oxford University Press.

Whittier, H.L. 1978b. Concepts of Adat and Cosmology among the Kenyah Dayak of Borneo. The Sarawak Museum Journal XXV, 47:103-113. 